\title{
ARSIP FOTO BAGI GENERASI MUDA MELALUI APLIKASI ARTO
}

\author{
Rina Rakhmawati*, Arif Rahman Bramantya*, \& Titi Susanti*
}

\author{
*Sekolah Vokasi Universitas Gadjah Mada \\ Email: rinaarsip@ugm.ac.id,arbramantya@ugm.ac.id, titisusanti@ugm.ac.id
}

(Submitted: 31-10-2-10, Revised: 30-01-2020, Accepted: 03-06-2020)

DOI: $10.24252 /$ kah.v8i1a4

\begin{abstract}
ABSTRAK: Artikel ini mendeskripsikan dan menganalisis prosedur pemanfaatan arsip foto sebagai media pembelajaran bagi generasi muda. Pemanfaatan arsip foto dalam wujud aplikasi permainan yang dikhususkan bagi usia sekolah dasar dan menengah. Arsip foto yang digunakan dalam aplikasi permainan tersebut diperoleh dari alih media arsip foto di Arsip Nasional Republik Indonesia dan unduhan portal resmi Koninklijk Instituut voor Taal-, Landen Volkenkunde (KITLV). Arsip foto terutama yang memiliki nilai kesejarahan beredar luas di media sosial dan menjadi daya tarik tersendiri. Namun tidak banyak masyarakat yang memahami prosedur pemanfaatan arsip foto sehingga tidak mencederai hak cipta yang melekat pada foto. Data dikumpulkan melalui observasi non-partisipasi, in-depth interview dan kajian pustaka, serta dianalisis dengan triangulasi data. Penelitian ini menyimpulkan bahwa perlunya mencantumkan sumber resmi dan hak cipta dari foto yang digunakan dengan metode watermark, penyebutan yang sesuai dengan standardisasi pendeskripsian arsip foto, serta pencantuman lokasi simpan asli dari arsip foto yang digunakan.
\end{abstract}

Kata kunci: Arsip foto; aplikasi arsip

\section{PHOTOGRAPH ARCHIEVES FOR YOUNG GENERATIONS THROUGH ARTO APPLICATION}

\begin{abstract}
This paper describes procedures for using photographic archives as a learning media for the young generation. The utilization of photo archives is in the form of game applications, especially elementary and middle school students. The photographic archives used in the game application were collected from digitalization process at the National Archives of the Republic of Indonesia and download in the official KITLV website. Photographic archives, especially those with historical values, are widely uploaded on social media and become uniquely historical information. However, not many of us understand the procedures utilizing photographic archives so that they do not irritated the copyright on the photos. The data were collected through nonparticipative observation, in-depth interviews, and literature reviews, and analyzed with data triangulation. The study found that there are needs to include official sources and copyrights of the photos used by the watermark method, the caption according to standardization of the description of the photographic archives, and the description of the original storage location of the photographic archives used.
\end{abstract}

Keywords: Photograph archives; archival application

\section{PENDAHULUAN}

Sejarah, memasuki era industri 4.0, mulai mendapat tempat istimewa di masyarakat. Bagi generasi muda, sejarah tak lagi sebatas masa lalu yang harus dihafalkan pada buku-buku pelajaran. Media sosial menjadikan sejarah lebih mudah dijangkau dan diminati oleh generasi 
muda. Berdasarkan pengamatan pada media sosial, terdapat 19 akun instagram, 16 akun twitter, 16 akun facebook, yang berfokus pada diseminasi informasi sejarah. Jika kita berbicara mengenai sejarah, maka tak lepas dari sumbernya, yaitu arsip.

Pada awalnya, istilah arsip di Indonesia, merujuk pada sekumpulan naskah yang diproduksi oleh institusi perkantoran. Naskah-naskah tersebut dilegalisasi melalui aturan naskah dinas resmi yang dikeluarkan oleh pemerintah. Selain itu, naskah tersebut juga disimpan berdasarkan pola klasifikasi baku yang telah ditetapkan secara legal formal. Sejalan dengan perkembangan teknologi media simpan, arsip tidak lagi dimaknai sebatas pada kumpulan naskah, tetapi juga muncul istilah arsip bentuk khusus. Menurut Sumrahyadi (dalam Mala dan Jumino, 2019), arsip bentuk khusus didefinisikan sebagai arsip yang media penyimpanan informasi tidak berasal dari kertas, seperti arsip film, foto, rekaman suara, dan video. Salah satu arsip bentuk khusus yang banyak digunakan dalam diseminasi informasi kesejarahan di media sosial adalah arsip foto. Menurut Fahrodji dan Prasetyawan (2019), arsip foto juga dikategorikan sebagai arsip gambar statik (still visual image), yaitu arsip yang isi informasinya terekam dalam citra gambar diam atau tidak bergerak.

Foto, pada mulanya dinilai sebagai visualisasi dari realita, tanpa ada penambahan sebagaimana dapat dilakukan oleh teknologi kamera saat ini. Peran foto sebagai citra real berbagai hal juga ditegaskan oleh Schwartz $(2000,68)$ bahwa photographs, because of their transparency and truth, were thus credited with being not only a way of seeing across space but also a way seeing those things - qualities, characteristics, emotions, values - that, in space, had no observable manifestation. Suatu peristiwa menjadi lebih mudah dipahami jika disertakan pula foto (Annie, 2016). No picture, hoax, menjadi istilah yang lazim disampaikan khususnya oleh generasi muda ketika mengklarifikasi suatu kejadian. Maka foto tidak lagi sebatas menjadi media dalam mencermati peristiwa, tetapi juga sebentuk cara dalam meyakini adanya peristiwa atau dengan kata lain trustworthy information system (Schwartz, 2000, 71). Oleh karena peran foto yang vital dalam membangun kepercayaan publik terhadap suatu peristiwa (Junior dan Rosenberg, 2007), tidak sedikit pihak yang mendiseminasikan peristiwa-peristiwa bersejarah dengan menyematkan foto-foto lama.

Sisi positifnya, masyarakat generasi sekarang menjadi semakin tercerahkan terkait dengan kehidupan masa lalu dan dinamika peristiwa yang melingkupinya. Namun perlu juga dicermati sisi negatif dari diseminasi informasi kesejarahan dengan memanfaatkan foto-foto lama. Dalam sebuah artikel berita disebutkan bahwa tidak sedikit narasi sejarah yang sifatnya fiktif meski menyertakan foto sebagai penguat (Edwards, 2014). Hal tersebut mengindikasikan bahwa tidak sedikit masyarakat yang belum memahami prosedur pemanfaatan arsip foto dan mengemas ulang informasi yang terekam di dalam foto tersebut.

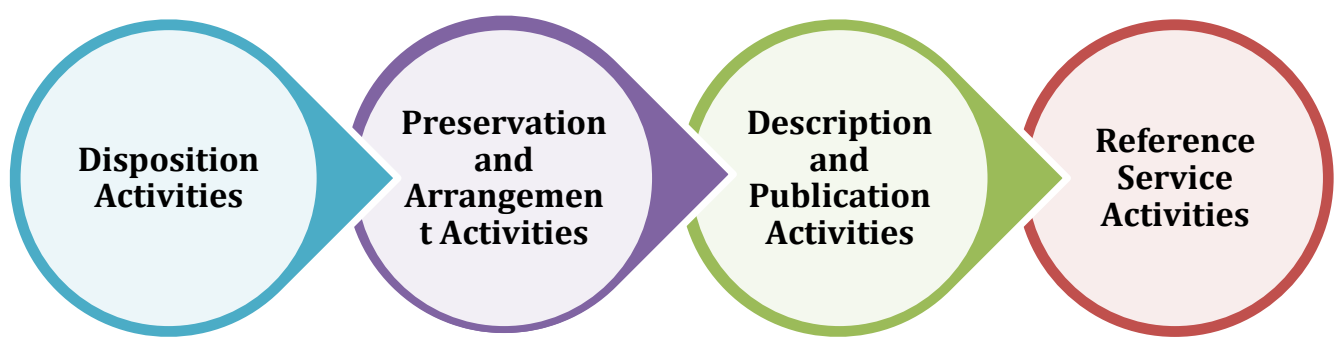

Bagan 1. Siklus Hidup Arsip Statis 
Pemanfaatan arsip dapat dikatakan sebagai sekumpulan kegiatan yang terdiri dari akses arsip, layanan referensi, penggandaan dan alih media arsip, hingga pemasyarakatan arsip. Arsip dapat dimanfaatkan setelah melalui proses pengelolaan. Menurut konsep siklus hidup arsip statis yang diinterpretasikan dari Schellenberg, pemanfaatan arsip dapat dicermati pada bagan di atas.

Berdasarkan gambar di atas, pemanfaatan arsip dikategorikan dalam kegiatan layanan arsip yang di dalamnya juga termasuk akses arsip. Selain melalui layanan arsip, pemanfaatan arsip juga dapat merujuk pada program pemasyarakatan arsip. Pada dasarnya, kegiatan layanan arsip dan program pemasyarakatan arsip dapat dikatakan saling melengkapi. Jika layanan arsip lebih ditekankan pada layanan yang diselenggarakan di dalam ruang layanan lembaga kearsipan, sedangkan program pemasyarakatan arsip lebih ditekankan pada berbagai kegiatan di luar ruang layanan lembaga kearsipan, seperti sosialisasi, pameran arsip, wisata arsip, dan sebagainya. Sedangkan menurut Bettington $(2008,135)$, pemanfaatan arsip merupakan bagian dari pemasyarakatan arsip sehingga terpisah dari bagian pengelolaan arsip statis yang hanya terdiri dari appraisal and disposal, acquisition, accessioning, dan arrangement and description.

Meski demikian, antara pengelolaan arsip dengan pemasyarakatan arsip tetap saling berkorelasi karena tujuan akhir dari pengelolaan arsip statis adalah mendayagunakan potensi arsip sebagai sumber informasi dan pengetahuan. Adapun pemanfaatan arsip pada makalah ini akan ditekankan pada tiga aspek, yaitu akses arsip, layanan arsip, dan pemasyarakatan arsip dalam bentuk diseminasi informasi. Tujuannya untuk mendeskripsikan dan menganalisis prosedur yang harus dipahami dan dilaksanakan oleh masyarakat dalam memanfaatkan arsip foto dan mengemas ulang informasi yang terekam dalam arsip foto tersebut. Prosedur tersebut bertujuan dalam menjaga autentisitas, validitas, dan reliabilitas media dan informasi arsip (Paula, 2014).

Menurut Jeremy, Woodley, dan Kupke (dalam Bettington, 2008), akses merupakan ...the terms and conditions of availability of records, documents or information maintained or held by an archive for evaluation or consultation by its users. International Council on Archives melalui standar General International Standard Archival Description (ISAD-G) mendefinisikan akses sebagai the ability to make use of material from a fonds, usually subject to rules and conditions. Berdasarkan definisi tersebut dapat disimpulkan bahwa akses mengacu pada ketersediaan dan keterjangkauan arsip, baik secara fisik maupun informasi, untuk dapat dimanfaatkan oleh masyarakat sesuai dengan syarat dan ketentuan yang berlaku di lembaga pengelola arsip.

Pemberlakuan akses didasarkan pada tiga aspek utama, yaitu legal authorization, existence of finding aids, dan conditions of archives (Jeremy, Woodley, dan Kupke dalam Bettington, 2008,). Akses menjadi kegiatan awal dalam kegiatan layanan arsip. Layanan arsip atau dalam berbagai literatur kearsipan disebut sebagai reference services merujuk pada makna ...the facilities and services afforded to reseachers and users of the archives and its records once access to them has been approved (Jeremy, Woodley, dan Kupke dalam Bettington, 2008).

Kajian terkait akses telah banyak diuraikan dalam berbagai penelitian. Dalam konteks internasional, kajian akses baru-baru ini tidak terbatas pada aspek prosedural atau kebijakan, tahapan, maupun jenis akses. Agostinho (2019) dalam publikasi berjudul Archival encounters: rethinking access and care in digital colonial archives mengkorelasikan langkah digitalisasi dan publikasi arsip kolonial oleh Arsip Nasional Denmark dalam rangka memperluas akses publik yang ternyata berbenturan dengan isu rights to be forgotten dan hak asasi manusia lainnya. Dalam kesimpulannya disebutkan bahwa ...digitization is never a merely technical process, shaped as it is by national and racial imaginaries, power differentials, affective economies of guilt and innocence and colonial legacies that continue to unevenly distribute both harm and privilege. Henttonen menyebutkan bahwa masyarakat saat ini telah memiliki mekanisme dalam melindungi hak privasi individu. Mekanisme tersebut antara lain: purpose limitation, privacy self-management and right to be forgotten, destruction, anonymization, and information safe haven approach (Henttonen, 2017). Oleh sebab itu, kajian yang dilakukan dua tahun sebelum Agostinho, Henttonen telah 
menegaskan bahwa arsiparis harus memahami kapan isu privasi mengemuka khususnya dalam lingkungan digital.

Dalam konteks Indonesia, kajian akses arsip masih berada pada cakupan kebijakan dan prosedur akses. Hal ini dapat diperhatikan pada kajian yang dilakukan oleh Indriati (2018), Setiawan (2017), serta Rahmawati dan Indrahti (2017). Adapun kajian yang menyoroti akses arsip dengan otomasi pun masih berada pada skop efisiensi dan efektivitas dalam penemuan kembali informasi (Tarigan dan Christiani, 2017; Nugraha, Widiyanto, dan Primadewi, 2018). Kajian berbeda dilakukan Aryani (2017) dengan menganalisis keterkaitan pengelolaan arsip film yang dilakukan swasta dengan isu pembatasan akses. Dalam kajian tersebut, dijelaskan bahwa apabila arsip film dikelola oleh pihak swasta, maka terdapat dua potensi akses:

1. Apabila dikelola oleh organisasi nirlaba, maka aksesnya akan mudah, khususnya dalam rangka mengapresiasi karya perfilman;

2. Apabila dikelola sejenis korporat, maka akses akan terikat pada hukum yang membatasi pemanfaatan arsip, termasuk di dalamnya terkait hak cipta

Berdasarkan kondisi demikian, Aryanti merekomendasikan agar arsip perfilman dikelola oleh lembaga pemerintah sehingga dapat peluang akses lebih besar. Berbeda dengan penelitian sebelumnya, dalam makalah ini penulis menyoroti konsep dan prosedur perlindungan hak cipta dan akses dalam konteks pemanfaatan arsip foto, khususnya yang digunakan untuk diseminasi informasi kesejarahan dan materi dasar pembuatan aplikasi.

Sebuah foto dapat dikatakan sebagai arsip apabila memenuhi kriteria: interrelatedness, dapat dipahami sebagai keterkaitan antara kegiatan atau peristiwa dengan arsip yang dihasilkan dari kegiatan atau peristiwa tersebut; uniqueness, dipahami sebagai keterkaitan antar dokumen dalam suatu lembaga kearsipan maupun antar dokumen dalam lembaga kearsipan yang berbeda; naturalness, dipahami sebagai arsip tercipta karena adanya kegiatan dan tidak disengajakan untuk diciptakan; impartiality, dipahami sebagai arsip diciptakan untuk memenuhi utamanya kepentingan pencipta arsip; dan authenticity, proses autentikasi terdiri dari autentikasi fisik media dan autentikasi format. Selain prosedur pemanfaatan dan kemas ulang informasi arsip foto, penulis juga perlu mendeskripsikan urgensi dan penyematan hak cipta yang melekat pada arsip foto. Hipotesis yang kemudian diajukan oleh penulis yaitu prosedur pemanfaatan dan kemas ulang informasi pada arsip foto adalah melalui suatu perizinan resmi dari lembaga yang berwenang mengelola arsip foto. Perolehan izin resmi sekaligus juga pernyataan pengguna arsip foto untuk mematuhi hak cipta yang ada pada arsip yang dimanfaatkan.

\section{METODOLOGI PENELITIAN}

Penelitian ini menggunakan penelitian kualitatif dengan pendekatan deskriptif eksploratif. Penelitian ini mengeksplorasi prosedur pemanfaatan arsip foto dan perlindungan terhadap hak cipta. Pemanfaatan arsip foto dalam hal ini tidak hanya berupa diseminasi di media sosial, tetapi juga sebagai material dasar perancangan aplikasi permainan. Data primer diperoleh melalui observasi partisipasi yang dilakukan oleh penulis saat mengakses arsip di sebuah lembaga kearsipan dan portal resmi KITLV. Selain itu, penulis juga berpartisipasi dalam proses perancangan aplikasi permainan ARTO. Selain itu, penulis juga melakukan penggalian informasi dari sejarawan yang juga pakar arsip foto. Data primer tersebut kemudian diolah dan dianalisis dengan data sekunder dari referensi pustaka terkait konsep pengelolaan arsip foto, serta konsep akses dan pemanfaatan arsip foto.

\section{HASIL DAN PEMBAHASAN}

\section{Arsip Foto dan Pengelolaannya}

Berbicara mengenai arsip foto, khususnya foto konvensional, maka juga berbicara mengenai media rekamnya. Arsip foto terdiri dari dua jenis media, yaitu foto positif dan foto negatif. Foto positif mengacu pada informasi yang terekam dalam kertas khusus yang digunakan untuk mencetak foto. Sedangkan foto negatif mengacu pada informasi yang terekam dalam media roll 
(Stylianou-Lambert, 2019). Dapat dikatakan bahwa foto negatif merupakan backup dari foto positif sehingga informasi dari foto positif dapat dicetak ulang. Dalam penelitian ini, arsip foto lebih merujuk pada foto positif.

Sebagaimana telah disampaikan bahwa media arsip foto memiliki perbedaan karakteristik dengan media arsip konvensional tekstual. Oleh sebab itu, meski pengelolaan secara umum memiliki tahapan yang tidak jauh berbeda, namun terdapat perbedaan perlakuan, khususnya pada tahapan penilaian, pengolahan, dan pelestarian (Radliani, Riyanto, dan Lestari, 2012). Adapun tahapan dalam pengelolaan arsip foto, khususnya arsip foto yang memiliki nilai guna kesejarahan, terdiri dari:

1) Tahapan akuisisi arsip, pada tahap ini, arsip foto diakuisisi bersamaan dengan arsip tekstual dalam suatu seri kegiatan sehingga tidak terlepas dari konteks penciptaannya;

2) Tahapan pengolahan arsip, terdiri dari penataan dan pendeskripsian. Hal-hal yang perlu dideskripsikan antara lain:

a. Subjek atau peristiwa atau masalah yang terekam dalam foto

b. Indeks, untuk memudahkan penelusuran arsip

c. Caption atau keterangan arsip foto (menggunakan prinsip 5W)

d. Asal arsip

e. Juru foto

f. Kode klasifikasi

g. Nomor foto negatif

h. Ukuran foto

Setelah dilakukan pendeskripsian, foto disimpan dalam amplop bebas asam dan ditata sesuai dengan nomor urut yang ada pada deskripsi foto. Perlu diperhatikan bahwa satu amplop hanya digunakan untuk menyimpan satu foto. Setelah itu, amplop tersebut disimpan dalam kotak penyimpanan khusus arsip foto. Fase akhir dari pengolahan arsip foto adalah penyusunan daftar arsip foto yang digunakan sebagai sarana penelusuran kembali arsip.

3) Tahapan pelestarian, secara garis besar, prosedur pelestarian arsip foto positif, yaitu:

a. Simpan foto dalam ruangan dengan kelembaban $40 \%-50 \%$ dan temperatur suhu 10-15 derajat celcius

b. Gunakan pencahayaan dengan lampu pijar atau lampu TL dengan daya ultra violet rendah

c. Jauhkah dari paparan sinar matahari maupun lampu secara langsung

d. Lakukan pembersihan dari debu dan serangga minimal 1 bulan sekali.

\section{Akses dan Pemanfaatan Arsip Foto pada Aplikasi ARTO}

Arsip merupakan sumber pengetahuan. Salah satu indikator suatu masyarakat memiliki budaya informasi adalah pemanfaatan arsip untuk meningkatkan literasi melalui keberadaan lembaga kearsipan. Dalam konsep daur hidup arsip, informasi terekam yang dapat diakses secara luas oleh publik ada pada arsip statis. Menurut Duranti dan Franks (2015), arsip statis dimaknai sebagai ...the whole of the documents made or received by a physical or judicial person in the course of activity and kept for further action or reference by this person or a legitimate successor. Definisi tersebut sejalan dengan konsep arsip statis dalam Undang-Undang Nomor 43 Tahun 2009 tentang Kearsipan, yaitu arsip yang dihasilkan oleh pencipta arsip karena memiliki nilai guna kesejarahan, telah habis retensinya, dan berketerangan dipermanenkan yang telah diverifikasi baik secara langsung maupun tidak langsung oleh Arsip Nasional Republik Indonesia dan/atau lembaga kearsipan. Agar dapat dimanfaatkan secara luas oleh publik, maka arsip statis harus tersedia, baik secara fisik maupun informasi. Secara sederhana, ketersediaan arsip, baik secara fisik maupun informasi, sehingga dapat dimanfaatkan oleh masyarakat luas disebut sebagai akses.

Menurut Jeremy, Woodley, dan Kupke (dalam Bettington, 2008), akses didefinisikan sebagai the terms and conditions of availability of records, documents, or information maintained or held by 
an archive for evaluation or consultation by its users. Berdasarkan definisi tersebut maka dapat dikatakan bahwa pemberian akses menjadi kewenangan lembaga kearsipan. Duranti dan Franks (2015) menambahkan bahwa pengguna yang mengakses arsip tidak hanya dibatasi pada personal maupun organisasi di luar pencipta arsip, tetapi dapat berupa teknologi dan proses bisnis atau aktivitas yang memang membutuhkan arsip. Sedangkan dalam perspektif kebijakan, General International Standard Archival Description (ISAD-G), akses diartikan sebagai the ability to make use of material from a fonds, usually subject to rules and conditions. Dalam konteks Indonesia, merujuk pada Undang-Undang Nomor 43 Tahun 2009 tentang Kearsipan, akses dipahami sebagai ketersediaan arsip sebagai hasil dari kewenangan hukum dan otorisasi legal serta keberadaan sarana bantu untuk mempermudah penemuan dan pemanfaatan arsip. Berdasarkan berbagai pendapat tersebut, maka akses dapat dipahami sebagai dua hal, yaitu ketersediaan arsip, baik fisik maupun informasi, dan kemampuan pengguna untuk dapat mengakses arsip atau dalam istilah lain disebut aksesibilitas.

Ketersediaan arsip dan kemampuan pengguna untuk dapat mengakses arsip tentu dipengaruhi oleh beberapa faktor, yaitu:

1. Kebijakan legal maupun yuridis, yaitu keberadaan perundang-undangan, prosedur, maupun standar yang menjadi landasan hukum akses arsip. Sebagaimana dipahami bahwa struktur informasi arsip berbeda dengan perpustakaan maupun museum. Meskipun arsip statis memiliki sifat terbuka, namun terdapat beberapa pengecualian yang berakibat pada pembatasan akses arsip. Pembatasan akses arsip statis terdapat dalam beberapa kebijakan, baik internasional maupun nasional:

a. International Council on Archives (ICA) melalui Principles of Access to Archives menegaskan bahwa arsiparis sebagai pengelola arsip harus mendukung iklim keterbukaan informasi. Namun demikian, dalam keterbukaan tersebut juga tetap harus memperhatikan ketentuan hukum, etika yang berlaku, serta hak dari pencipta maupun pemilik arsip untuk menutup informasi - informasi tertentu.

b. Undang-Undang Nomor 14 Tahun 2008 tentang Keterbukaan Informasi Publik menyebutkan dua jenis informasi, yaitu informasi yang wajib disediakan dan diumumkan, serta informasi yang dikecualikan. Terkait dengan akses arsip maka yang perlu diperhatikan dengan seksama adalah informasi yang dikecualikan.

c. Undang-Undang Nomor 43 Tahun 2009 tentang Kearsipan dan Peraturan Pemerintah Nomor 28 Tahun 2012 tentang Pelaksanaan Undang-Undang Nomor 43 Tahun 2009 tentang Kearsipan, dalam salah satu pasalnya menyebutkan bahwa lembaga kearsipan memiliki kewenangan menetapkan keterbukaan arsip statis sebelum 25 (dua puluh lima) tahun masa penyimpanan yang dinyatakan masih tertutup dengan pertimbangan:

1) tidak menghambat proses penegakan hukum;

2) tidak mengganggu kepentingan pelindungan hak atas kekayaan intelektual dan pelindungan dari persaingan usaha tidak sehat;

3) tidak membahayakan pertahanan dan keamanan negara;

4) tidak mengungkapkan kekayaan alam Indonesia yang masuk dalam kategori dilindungi kerahasiaannya;

5) tidak merugikan ketahanan ekonomi nasional;

6) tidak merugikan kepentingan politik dan hubungan luar negeri;

7) tidak mengungkapkan isi akta autentik yang bersifat pribadi dan kemauan terakhir ataupun wasiat seseorang kecuali kepada yang berhak secara hukum;

8) tidak mengungkapkan rahasia atau data pribadi; dan

9) tidak mengungkapkan memorandum atau surat-surat yang menurut sifatnya perlu dirahasiakan.

Kebijakan-kebijakan tersebut juga berlaku untuk arsip foto. Sebagaimana diketahui, foto memiliki karakter yang lebih lugas dalam memberikan visualisasi suatu kegiatan atau peristiwa. Hak privasi individu akan mudah dideskripsikan dengan jelas melalui foto, 
khususnya peristiwa yang bersifat tragedi dan hal-hal tidak menyenangkan lainnya (Baron dan Payne, 2017). Adanya kebijakan yang menetapkan akses arsip foto, diharapkan pengguna dapat lebih berhati-hati dan cermat dalam memanfaatkan arsip foto yang berisikan konten sensitif. Oleh sebab itu, meski terlihat sederhana, penetapan pembatasan akses untuk arsip statis pada dasarnya kompleks karena melibatkan aspek sosial, budaya, keterkaitan dengan proses bisnis dari pemilik atau pencipta atau subjek yang terekam dalam foto, dan juga persoalan hak asasi manusia (Upward, Reed, Oliver, Evans, 2018). Persetujuan dari pihak lembaga kearsipan maupun pencipta dan/atau pemilik arsip menjadi mutlak diperlukan. Dalam konteks aplikasi ARTO, arsip foto yang digunakan dapat dikategorikan sebagai informasi yang terbuka sehingga tidak memerlukan perizinan yang lebih khusus kepada pencipta atau pemilik arsip foto.

2. Keberadaan sarana temu kembali (finding aids). Secara sederhana, sarana temu kembali arsip diartikan sebagai guides produced to assist users to access archival collections (Darnell dalam Bettington, 2008, 379). Melalui sarana temu kembali diharapkan pengguna dapat menelusuri arsip yang dibutuhkan. Namun demikian, informasi yang direkam dalam sarana temu kembali arsip tidak mendetail sebab fungsi sarana temu kembali hanya sebagai media yang memudahkan pengguna untuk menemukan arsip. Berbeda dengan pengguna perpustakaan yang dapat menemukan langsung bahan pustaka yang dibutuhkan, dalam penelusuran arsip diperlukan sarana temu kembali arsip untuk memudahkan pengguna memahami konteks penciptaan arsip. Dalam konteks arsip konvensional, sarana temu kembali terdiri dari general guides, guide to finding aids, summary guides, inventories, control records, dan supplementary finding aids (Darnell dalam Bettington, 2008). Sedangkan sarana temu kembali yang dikenal dan disusun oleh lembaga kearsipan di Indonesia, menurut Peraturan Kepala Arsip Nasional RI Nomor 27 Tahun 2011 tentang Pedoman Penyusunan Sarana Temu Kembali Arsip Statis, terdiri dari: guide arsip statis, daftar arsip statis, dan inventaris arsip. Seiring dengan perkembangan teknologi informasi, sarana temu kembali berkembang menjadi sebuah sistem informasi laiknya mesin pencari Google.

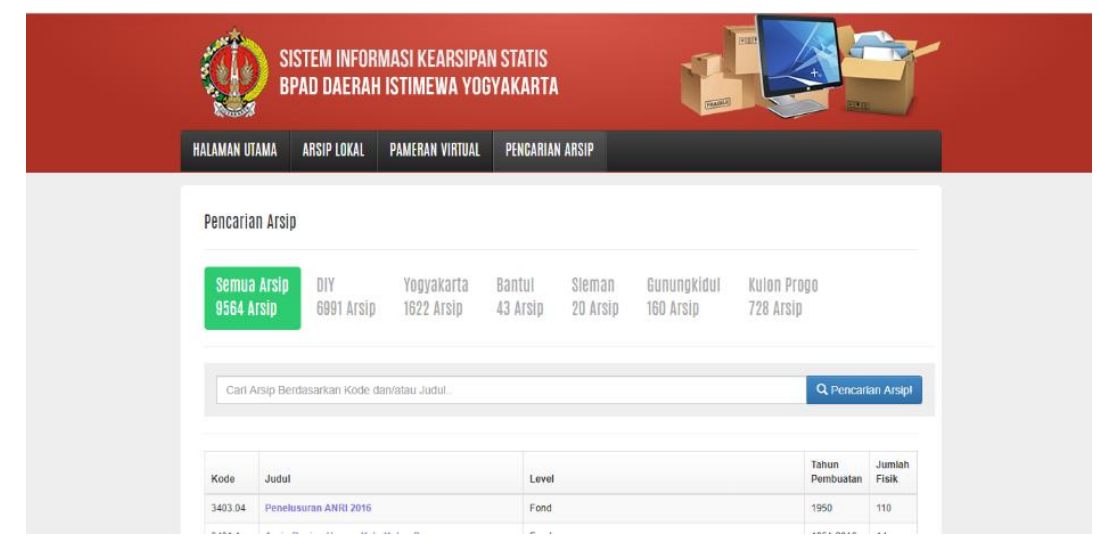

Gambar 1. Contoh laman untuk pencarian arsip

Fungsi ideal dari sistem penelusuran arsip berbasis online seharusnya lebih memudahkan pengguna dalam menelusuri informasi yang terekam dalam arsip dengan lebih efektif, efisien, dan akurat. Melalui sarana penelusuran arsip berbasis online, publik dapat memastikan keberadaan arsip dan informasi yang dibutuhkan (Wood, 2018). Namun tidak sedikit ditemukan hasil penelusuran arsip yang masih perlu dilakukan pengembangan dan evaluasi. Hal tersebut harus dilakukan agar pengguna dapat lebih memastikan jika arsip yang ditemukan melalui sistem tersebut memang tepat dan tersedia tanpa harus menelusuri ulang di lembaga kearsipan. 




Gambar 2. Contoh Sarana Penelusuran Arsip Berbasis Online

Fungsi ideal dari sistem penelusuran arsip berbasis online seharusnya lebih memudahkan pengguna dalam menelusuri informasi yang terekam dalam arsip dengan lebih efektif, efisien, dan akurat. Melalui sarana penelusuran arsip berbasis online, publik dapat memastikan keberadaan arsip dan informasi yang dibutuhkan (Wood, 2018). Namun tidak sedikit ditemukan hasil penelusuran arsip yang masih perlu dilakukan pengembangan dan evaluasi. Hal tersebut harus dilakukan agar pengguna dapat lebih memastikan jika arsip yang ditemukan melalui sistem tersebut memang tepat dan tersedia tanpa harus menelusuri ulang di lembaga kearsipan.
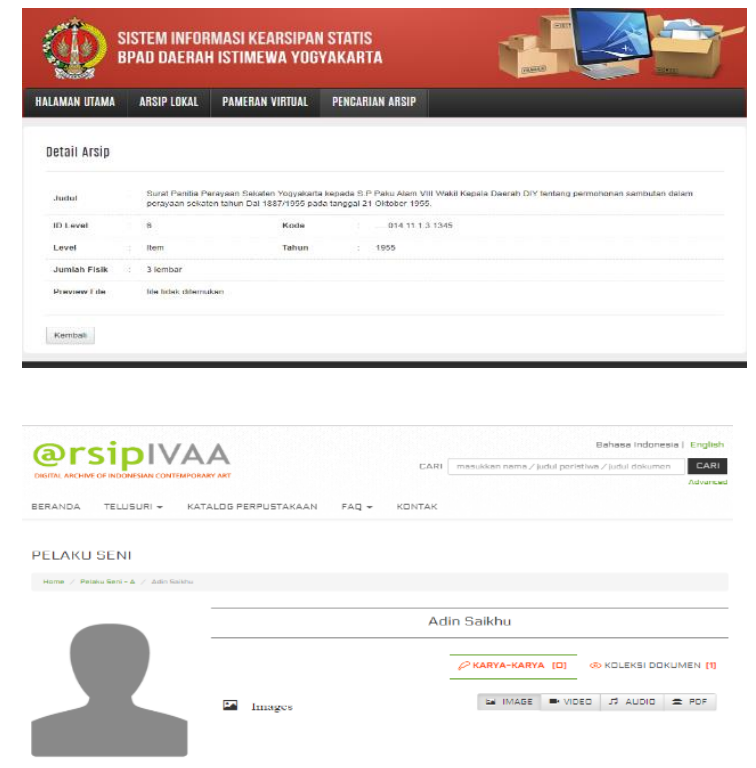

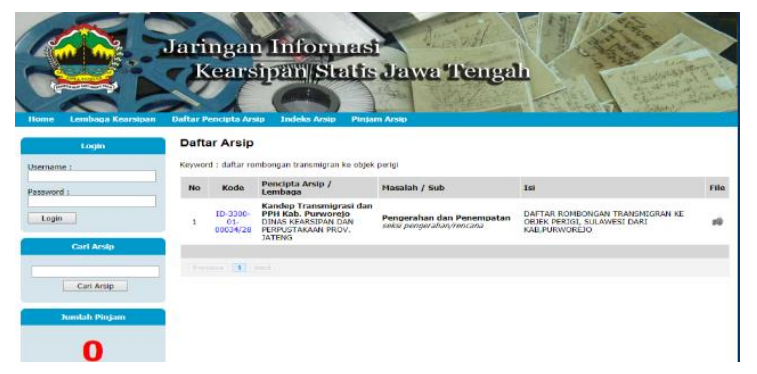

Gambar 3. Hasil penelusuran berbasis online yang harus diperbaiki 


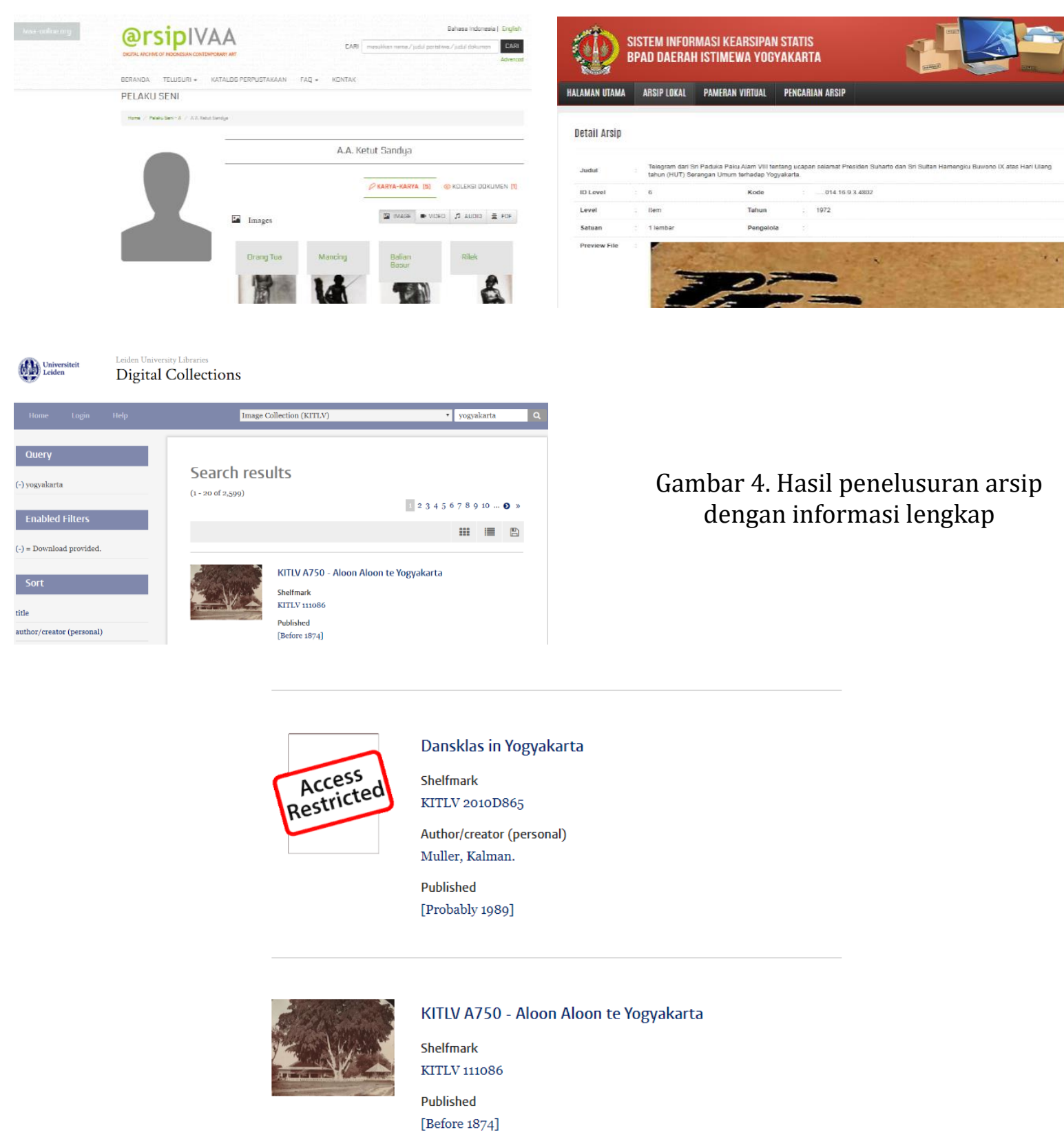

Gambar 4. Hasil penelusuran melalui portal resmi KITLV

Dalam konteks pemanfaatan arsip foto yang digunakan dalam aplikasi ARTO, arsip tersebut diperoleh melalui akses pada lembaga kearsipan Arsip Nasional Republik Indonesia (ANRI) dan sebagian berasal dari unduhan pada portal KITLV Belanda. Untuk memperoleh arsip yang dibutuhkan, penulis melakukan penelusuran arsip terlebih dahulu melalui portal resmi KITLV dengan kata kunci "Yogyakarta" hingga diperoleh hasil seperti gambar di atas.

Pada hasil penelusuran tersebut diperoleh beberapa arsip yang dapat langsung diakses dan diunduh, dan ada sebagian arsip yang aksesnya dibatasi. Untuk akses yang dibatasi tersebut, pengguna harus menghubungi pihak KITLV untuk memperoleh perizinan resmi sehingga dapat dimanfaatkan. Sedangkan arsip yang dapat diakses, pengguna dapat langsung mengunduh dengan memperhatikan ketentuan penggunaan sebagai berikut: 


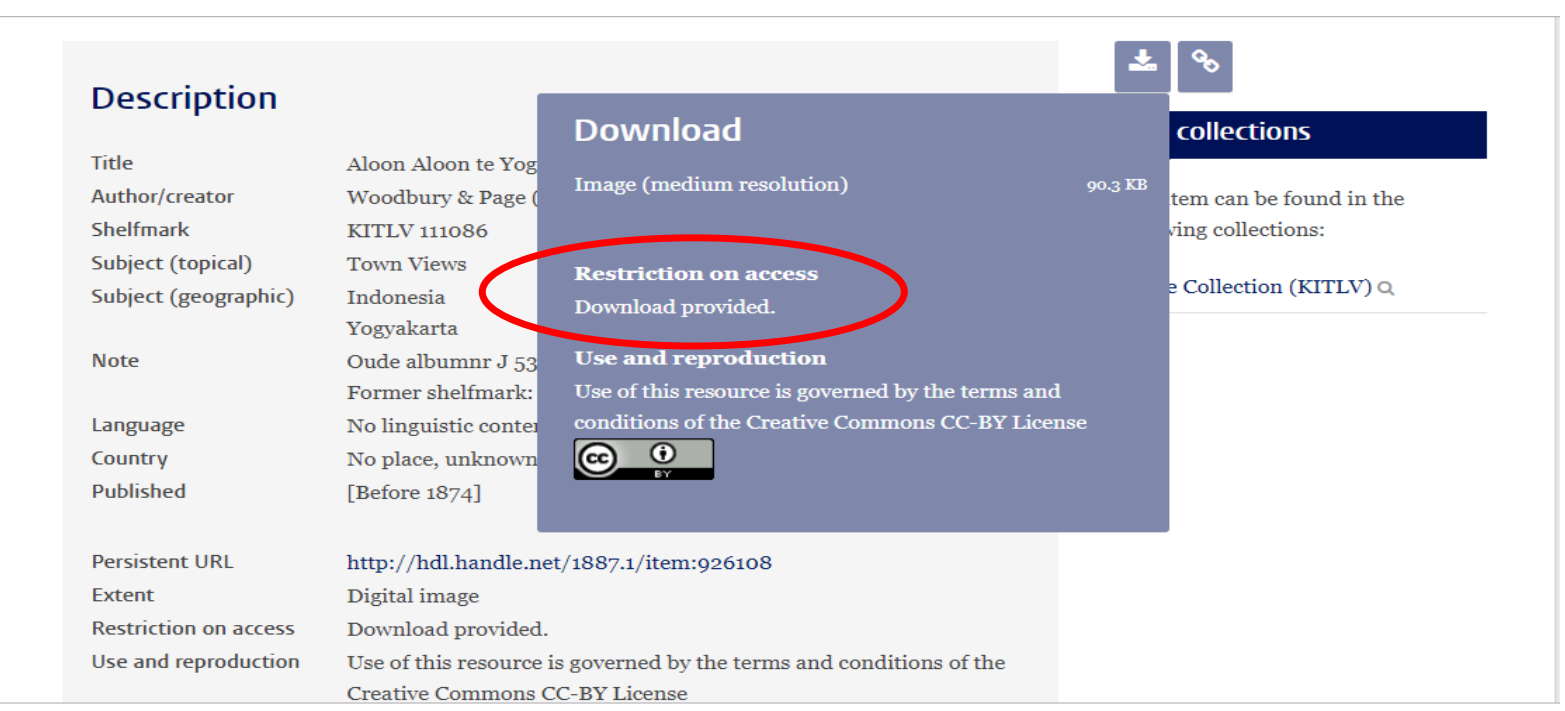

Pada bagian Use and reproduction terdapat logo "CC BY". Dalam aturan lisensi, logo tersebut bermakna mengizinkan setiap pengguna untuk mengubah, memperbaiki, dan membuat ciptaan turunan, bahkan untuk kepentingan komersial, selama dalam penggunannya dicantumkan kredit atas ciptaan asli. Pada arsip dengan akses terbuka tersebut, kualitas foto berada pada kualitas telah dilakukan kompresi sehingga mudah untuk diunggah dan didiseminasikan melalui portal internet. Adapun arsip yang diperoleh melalui lembaga kearsipan (dalam penelitian ini adalah ANRI), maka melalui prosedur perizinan sebagai berikut:

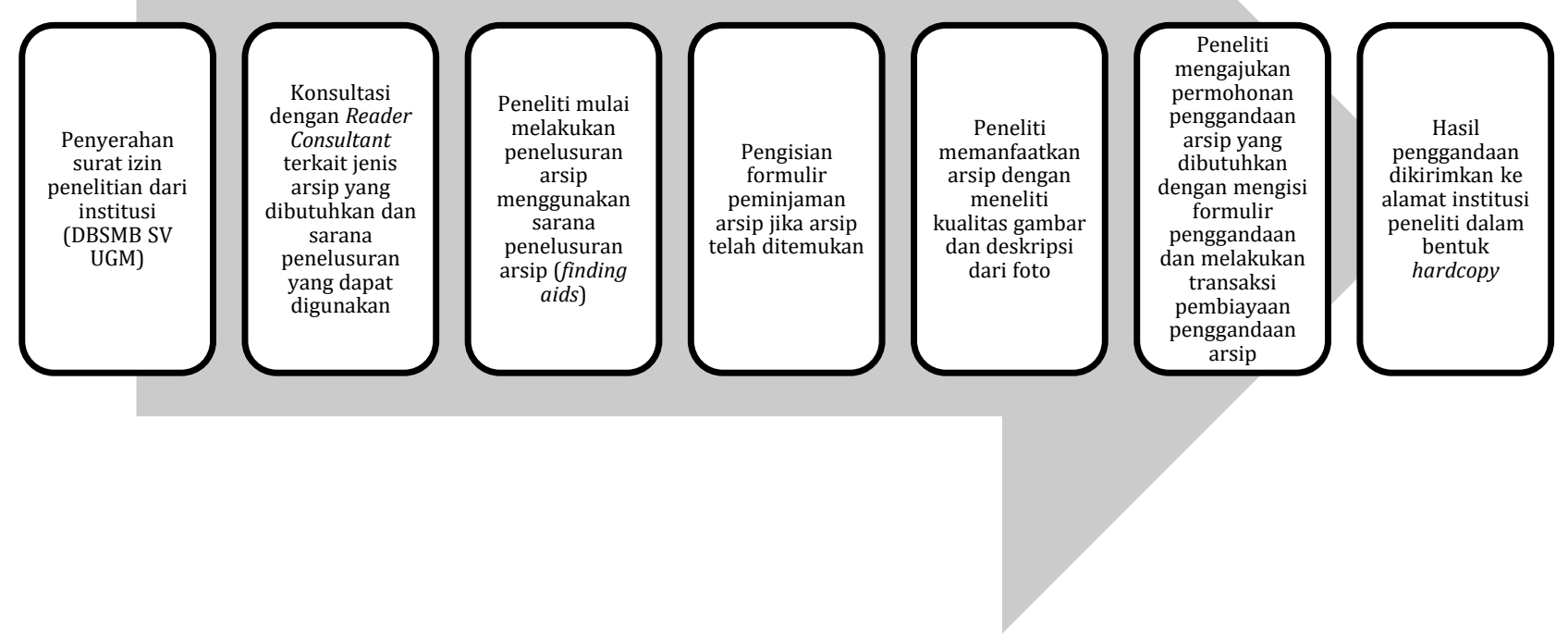

Bagan 2. Alur Perizinan Pemanfaatan Arsip Foto (Sumber: Hasil Olah Sumber Prosedur Layanan Arsip di Arsip Nasional RI) 


\section{DISKUSI}

Kajian mengenai arsip foto di Indonesia telah banyak difokuskan pada aspek teknik pengelolaan. Meski demikian, kajian teknis pengelolaan masih pada taraf pengelolaan arsip foto dalam wujud konvensional. Selain itu, jika berdiskusi perihal pengelolaan arsip, maka harus pula dikaitkan dengan aspek pemanfaatan arsip. Hal ini disebabkan tujuan utama dari pengelolaan arsip adalah pemanfaatan arsip untuk meningkatkan literasi informasi masyarakat.

Meski demikian, pemanfaatan arsip foto juga perlu memperhatikan batasan tertentu yang diatur dalam berbagai kebijakan mengenai akses dan penggunaan arsip. Keberadaan pembatasan akses pada arsip-arsip tertentu, termasuk arsip foto, tidak kemudian membatasi kebebasan dalam diseminasi informasi. Pembatasan akses dilakukan dalam rangka perlindungan terhadap hak-hak pribadi dan perlindungan terhadap hak cipta yang melekat pada arsip foto. Kajian dalam penelitian ini berkontribusi pada aspek pengembangan kebijakan akses dan penggunaan arsip, khususnya arsip foto. Konsep memudahkan akses dan penggunaan perlu diimplementasikan dengan tidak mencederai hak-hak privasi dan hak cipta. Namun, kajian ini masih memiliki keterbatasan yang perlu dilakukan pengembangan dan pendalaman penelitian. Belum adanya aspek persepsi pengguna secara lebih luas menjadi tantangan dalam analisis penelitian selanjutnya sehingga tidak terbatas pada konteks pemanfaatan arsip untuk keperluan perancangan aplikasi tertentu.

\section{KESIMPULAN}

Di era media sosial, informasi menjadi kunci utama menuju perbaikan yang berkelanjutan. Informasi yang menjadi kunci utama tersebut haruslah memiliki karakter reliabel, otentik, kontekstual, dan mudah diakses. Informasi yang memiliki karakter tersebut adalah arsip. Arsip di era serba terkoneksi tidak lagi dipahami sebatas pada sekumpulan dokumen yang bersifat administratif. Arsip tidak lagi sebatas pada dokumen dengan konten berisi kumpulan teks yang bagi sebagian masyarakat, sulit untuk dipahami. Arsip dapat juga terekam dalam wujud foto, sebuah citra yang mudah diingat dan ditangkap oleh keterbatasan memori manusia.

Arsip foto mulai banyak dimanfaatkan untuk menyebarluaskan berbagai peristiwa bersejarah. Tidak sedikit komunitas kesejarahan dengan media sosialnya, memanfaatkan arsip foto dan menyusun narasi sejarah berdasarkan foto yang diposting. Namun demikian, tidak sedikit yang justru abai dengan batasan akses dalam memanfaatkan arsip foto tersebut sehingga muncul pemalsuan narasi sejarah. Keberadaan akses arsip, termasuk arsip foto, merupakan sebuah upaya untuk melindungi hak cipta dan hak privasi yang juga melekat pada arsip tersebut. Dalam konteks perancangan aplikasi ARTO, penulis melakukan akses dan pemanfaatan arsip sesuai prosedur yang diberlakukan dalam kebijakan kearsipan, terutama pencantuman asal arsip dan narasi yang disesuaikan dengan deskripsi yang melekat pada arsip foto.

Dalam mengakses dan memanfaatkan arsip foto, masyarakat harus mencermati terlebih dahulu kebijakan yang melingkupi akses dan penggunaan arsip. Sebagian arsip dapat diakses dengan mudah melalui portal resmi, namun tidak sedikit yang mengharuskan pengguna untuk berkomunikasi melalui perizinan resmi kepada lembaga kearsipan sebagai pengelola resmi arsip. Dalam kaitannya dengan perizinan resmi tersebut, lembaga kearsipan pun telah melakukan perubahan signifikan sehingga pengguna dapat lebih mudah mengakses arsip yang diperlukan. Meski demikian, lembaga kearsipan masih perlu melakukan perbaikan signifikan, khususnya dalam hal pemanfaatan internet sebagai sarana penelusuran arsip.

\section{DAFTAR PUSTAKA}

Junior, F. X. B., \& Rosenberg, W. G. (2007). Archives, Documentation, and Institutions of Social Memory: Essays from The Sawyer Seminar. Michigan: The University of Michigan Press.

Bettington, J. (2008). Keeping Archives. Melbourne: Australian Society of Archivists Inc. 
Duranti, L., \& Franks, P. J. (2017). Encyclopedia of Archival Science. Canada: Rowman and Littelfield.

Baron, J. R., \& Payne, N. (2017). Dark Archives and eDemocracy: Strategies for Overcoming Access Barriers To The Public Record Archives of The Future. International Conference for EDemocracy and Open Government (p.3-11). Krems.

Wood, K. (2018). Reference and Access: Innovative Practices for Archives and Special Collections. Archives and Manuscripts Journal, 46(1).

Henttonen, P. (2017). Privacy as An Archival Problem and A Solution. Archival Science Journal, 17.

Paula, M. S. (2014). Reconstructing memory through the archives: public pedagogy, citizenship and Letizia Battaglia's photographic record of mafia violence, Pedagogy, Culture \& Society, 22:1, 97-116, DOI: $10.1080 / 14681366.2013 .877620$

Annie, E. C. (2016) Photography against the grain: rethinking the colonial archive in Kenyan museums, World Art, 6:1, 61-83, DOI: 10.1080/21500894.2015.1126853

Edwards, E. (2014) Photographic Uncertainties: Between Evidence and Reassurance, History and Anthropology, 25:2, 171-188, DOI: 10.1080/02757206.2014.882834

Stylianou-Lambert, T. (2019) Photographic Ecosystems and Archives, photographies, 12:3, 375394, DOI: $10.1080 / 17540763.2019 .1625808$

Radliani, A. H, Riyanto, A., \& Lestari, N. (2012). Analisis Pengelolaan Arsip Foto di Arsip Universitas Gadjah Mada. Jurnal Ilmu Perpustakaan, 1(1).

Aryani, P. D. (2017). Pengelolaan Arsip Film Oleh Swasta dan Jaminan Akses Publik. Pakuan Law Review, 3(2).

Mala, C., \& Jumino, J. (2019). Digitalisasi Produk Rekaman Studio Lokananta Dalam Rangka Melestarikan Arsip Rekaman Suara Di Studio Lokananta. Jurnal Ilmu Perpustakaan, 6(3), 301-310.

Fahrodji, I. F., \& Prasetyawan, Y. Y. (2019). Kajian Pengolahan Arsip Gambar Statik Sebagai Upaya Penyelamatan Nilai Informasi Arsip Di Dinas Kearsipan Dan Perpustakaan Provinsi Jawa Tengah. Jurnal Ilmu Perpustakaan, 6(4), 371-380.

Schwartz, J. M. (2000). "Records of Simple Truth and Precision": Photography, Archives, and the Illusion of Control. Archivaria, 50, 1-40.

Agostinho, D. (2019). Archival encounters: rethinking access and care in digital colonial archives. Archival Science, 19(2), 141-165.

Indriati, B. (2018). Pemanfaatan Hasil Pengolahan Arsip Statis Melalui Layanan Akses di Dinas Perpustakaan dan Kearsipan Kabupaten Sleman. Khazanah: Jurnal Pengembangan Kearsipan, 11(2), 14-27.

Setiawan, M. V. (2017). Akses dan Layanan Arsip Statis di Lembaga Kearsipan Universitas Gadjah Mada. LIBRARIA: Jurnal Ilmu Perpustakaan Dan Informasi, 47-62.

Rahmawati, F. A., \& Indrahti, S. (2017). Evaluasi Implementasi Kebijakan Layanan Arsip Statis Di Badan Arsip Dan Perpustakaan Daerah Provinsi Jawa Tengah. Jurnal Ilmu Perpustakaan, 6(1).

Tarigan, E. A., \& Christiani, L. (2019). Pemanfaatan Jaringan Informasi Kearsipan Statis Dalam Mendukung Akses Dan Layanan Arsip Statis Di Dinas Kearsipan Dan Perpustakaan Provinsi Jawa Tengah. Jurnal Ilmu Perpustakaan, 6(2), 21-30.

Nugraha, J. A., Widiyanto, A., \& Primadewi, A. (2018). Sistem Pengelolaan Arsip Dengan Menerapkan Manajemen Akses User Berbasis Web Pada Yppalb B (Tunarungu Wicara) Kota Magelang. Jurnal Komtika, 2(1), 49-54.

Undang-Undang Nomor 43 Tahun 2009 tentang Kearsipan 